\title{
Spatial organization and social relations in the Eurasian lynx population in Białowieża Primeval Forest, Poland
}

\author{
Krzysztof SCHMIDT, Włodzimierz JĘDRZEJEWSKI and Henryk OKARMA
}

Schmidt K., Jędrzejewski W. and Okarma H. 1997. Spatial organization and social relations in the Eurasian lynx population in Bialowieża Primeval Forest, Poland. Acta Theriologica 42: 289-312.

The home range size, spacing pattern and intraspecific relations in the lynx Lynx lynx (Linnaeus, 1758) were studied in Białowieża Primeval Forest (eastern Poland), in 1991-19S6. Eighteen lynx (11 males and 7 females) were captured and radio-collared. The mean autumn-winter home range size was $165 \mathrm{~km}^{2}$ for males and $94 \mathrm{~km}^{2}$ for females. In spring-summer, it was 143 and $55 \mathrm{~km}^{2}$, respectively. The mean life-time home ranges were $248 \mathrm{~km}^{2}$ for males and $133 \mathrm{~km}^{2}$ for females. Male home range size did not change significantly between autumn-winter and spring-summer seasons, however, their ranges increased by $40-90 \%$ just before and during the mating season (December-March). The home range of females in the autumn-winter season was almost twice as large compared with the spring-summer period (94 vs $55 \mathrm{~km}^{2}$ ). The smallest home ranges were observed in breeding females during the two months after parturition $\left(10 \mathrm{~km}^{2}\right)$ and these grew until the following spring. The home ranges calculated for 5-month periods shifted on average $4 \mathrm{~km}$ in adult males, 2.7 in adult females and $4.7 \mathrm{~km}$ in subadult males. One of the farthest shifts in the adult male range $(8.7 \mathrm{~km})$ was explained by the death of a neighbouring resident. The average overlap between adult males' ranges was $30 \%$, while those between females was $6 \%$. The largest overlap occurred between adult males and females $(62 \%)$ as well as between adult and subadult males $(75 \%)$. The lynx showed a tendency to avoid each other. The average distance between neighbouring adult males was $11.6 \mathrm{~km}$, and they were never found closer than $1 \mathrm{~km}$ to each other. The average distance between neighbouring females was $8.1 \mathrm{~km}$. Besides a few meetings between males and females (during and outside the mating season), they were located separately (4.4 km from each other, on average). In $93 \%$ of the cases an adult female was recorded with her dependent kittens. It was concluded that home range size and spacing pattern in male lynx depend on the distribution of females, whereas spacing in females was determined by food-related factors.

Key words: Lynx lynx, home range size, territoriality, overlap, sociality, radio-tracking Mammal Research Institute, Polish Academy of Sciences, 17-230 Białowieża, Poland; e-mail: kschmidt@bison.zbs.bialowieza.pl (KS),wlodek@bison.zbs.bialowieza.pl (WJ)

\section{Introduction}

The spatial organization of the Eurasian lynx Lynx lynx (Linnaeus, 1758) has been poorly studied in comparison with its North American congeneric, the Canada lynx L. canadensis, and the bobcat $L$. rufus (eg Bailey 1974, Mech 1980, Carbyn 
and Patriquin 1983, Parker et al. 1983, Ward and Krebs 1985, Giddings 1986, Litvaitis et al. 1986, 1987, Koehler and Hornocker 1989, Poole 1994, 1995). Studies of Eurasian lynx conducted in the former USSR (Yurgenson 1955, Shubin 1967, Zheltukhin 1984, 1986), Sweden (Haglund 1966), Norway (Dunker 1988), and Finland (Pulliainen 1980) were based on snow-tracking and presented mainly dietary analyses.

Radio-telemetry research by Haller and Breitenmoser (1986) and Breitenmoser et al. (1993) have provided interesting data on the spatial organization of Eurasian lynx in the Alps and Jura Mountains. However, the subject of these studies was a population reintroduced in the 1970s (Breitenmoser and Breitenmoser-Würsten 1990), which is still in expansion and in the process of adaptating to a new environment. Moreover, the Swiss population of the lynx is isolated from the main range of the species and lives in habitats highly transformed and densely populated by people.

Populations of lynx inhabiting the Białowieża Primeval Forest (BPF) (Poland and Belarus), are on the western limit of the contemporary natural, continuous range of this species (Matjuschkin 1978). In the past, periods of heavy persecution (1890-1914 and 1960-1970) led to severe declines of lynx in BPF (Jędrzejewski et al. 1996). Contemporarily, the lynx population in BPF has been protected and is largely shaped by natural factors, although some poaching does occur. During the study, lynx were shot in small numbers in the Belarussian part of BPF. In Białowieża Forest, lynx hunt predominantly roe deer Capreolus capreolus and red deer Cervus elaphus (Jędrzejewski et al. 1993). The mean density of lynx estimated from 1992 to 1994 was 5 individuals per $100 \mathrm{~km}^{2}$ (Jędrzejewski et al. 1996).

This study was conducted in the Polish part of BPF in 1991-1996. Based predominantly on data derived from radio-telemetry our objectives were to: (1) estimate the size of lynx home range and describe its seasonal and long-term dynamics; (2) reveal the spatial structure of the population, ie the extent of home range overlap within and between sexes; and (3) evaluate social relations among individuals of different sex and age. Finally we discussed factors affecting spatial structure of the lynx population.

\section{Study area}

BPF, located on the Polish-Belarussian border, is among the best preserved natural deciduous and mixed lowland forests in Europe (Faliński 1986). Total area of BPF is $1250 \mathrm{~km}^{2}$, of which $580 \mathrm{~km}^{2}$ is in Poland. The Polish part of BPF $\left(52^{\circ} 30^{\prime}-53^{\circ} \mathrm{N}, 23^{\circ} 30^{\prime}-24^{\circ} 15^{\prime} \mathrm{E}\right)$ includes Białowieża National Park (BNP, $47.5 \mathrm{~km}^{2}$ ) (a strict reserve since 1921), and the exploited forest. Almost half of BNP is primarily covered by deciduous forest, composed of oak Querqus robur, lime Tilia cordata, and hornbeam Carpinus betulus. Other types of forest are mixed coniferous forests (with pine Pinus silvestris and spruce Picea abies) and wet alder Alnus glutinosa and ash Fraxinus excelsior forests. The exploited forest is dominated by mixed coniferous forest (58\% of area). Bog alderwoods and oak-lime-hornbeam forests occupy smaller portions of the area (Jędrzejewska et al. 1994). The average age of tree stands in the whole BPF is 77 years (Jędrzejewska et al. 1994). In contrast to other European woodlands, Białowieża Forest is rather continuous, with only a few glades with villages (total area of glades 
located in the Polish and Belarussian parts of BPF does not exceed 5\%). Except for timber exploitation and hunting, there is little human activity in the forest.

The terrain of BPF is flat, on average $165 \mathrm{~m}$ a.s.1., with maximum amplitude of $68 \mathrm{~m}$ (range 134-202 $\mathrm{m}$ a.s.l.). The climate of BPF is transitional between continental and atlantic types with clearly marked cold and warm seasons (Olszewski 1986). The mean January and July temperatures during the study were $-2.4^{\circ} \mathrm{C}$ and $20.1^{\circ} \mathrm{C}$, respectively. Mean annual precipitation was $571 \mathrm{~mm}$. In various winters snow cover persisted from 27 to 152 days. The maximum recorded snow depth (in 1995/96) reached $63 \mathrm{~cm}$.

In BPF the community of ungulates consists of European bison Bison bonasus, moose Alces alces, red deer, roe deer, and wild boar Sus scrofa. During the study (1991-1996), the winter densities of roe deer declined from 492 to $324 / 100 \mathrm{~km}^{2}$, as did those of red deer, from 607 to $463 / 100 \mathrm{~km}^{2}$ (Okarma et al. 1997).

\section{Material and methods}

\section{Capturing and radio-tracking of lynx}

A total of 18 lynx (11 males and 7 females) were captured in the Polish part of BPF, radio-collared and followed from February 1991 to March 1996 (Appendix). The animals were captured with footsnare traps (Quinn and Parker 1987) at fresh kills or marking places (16 captures including 2 recaptures) and in a double-door box trap ( 5 captures including 1 recapture). All traps were equipped with a radio-alarm system which shortened the time the lynx spent in a trap to 1-2 hours. The lynx were immobilized with $0.4-1.0 \mathrm{ml}$ xylazine-ketamine mixture ( $583 \mathrm{mg}$ Bayer "Rompun" dissolved in $4 \mathrm{ml}$ Parke-Davis "Ketavet" $100 \mathrm{mg} / 1 \mathrm{ml}$ ) (Seal and Kreeger 1987). The sex of the lynx was determined and age (yearling or adult) was estimated on the basis of body mass, date of capture, and tooth wear. The animals were fitted with radio-collars $(220 \mathrm{~g}$; A. Wagener, Köln, Germany and AVM Instrument Co., California, USA). After handling, the lynx were injected with $0.4-1.0 \mathrm{ml}$ of etilefrinum hydrochloricum (Boehringer Ingelheim "Effortil") to help recover normal heart action.

All radio-collared lynx were localized from the ground 5-7 times each week (signal range was $1-3 \mathrm{~km}$ ). In order to fix a location of an animal we used the regular grid of forest compartment lines $1066 \times 1066 \mathrm{~m}$. The compartments were divided into 4 quarters, and there were forest roads along every one or second line, which enabled us to reach 2-3 corners of each square. Following standard triangulation techniques (Mech 1983), we aimed to determine in which quarter the lynx was located. In 1991-1993, the radio-tracking was done in the Polish part of BPF, and only few approximate localizations from the Belarussian part made from the church tower in Białowieża village (with accuracy 1-2 km, as tested by checking the bearings from the ground in Polish part of BPF) are included. In 1994, radio-tracking was also occasionally conducted in the Belarussian part. In addition to daily locations, continuous 5-day radio-tracking sessions of individual lynx were conducted once a month in 1994 and 1995, and 1-5 day sessions (but less regularly) in 1991-1993.

Because of large home ranges of lynx and the fairly short signal range of transmitters in the dense forest, our efforts to locate the lynx were successful only in $19-76 \%$ of all the days during which the particular lynx wore active collars. Thus, the home range of some individuals, especially those which were located also outside the state border may be underestimated (see Appendix). They were used for some analyses only. However, the locations of lynx living farther from the border were represented sufficiently. In total, 1912 radio-locations were collected. The radio-tracking time of particular individuals varied from 1 to 26 months (mean $=10.7, \mathrm{SD}=7$; Appendix).

\section{Home range estimation}

We used Minimum Convex Polygon as the main method to estimate home range size (Hayne 1949). This is the most frequently used home range estimator (eg Hemker et al. 1984, Litvaitis et al. 1986, 
Haller and Breitenmoser 1986, Crawshaw and Quigley 1991, Breitenmoser et al. 1993, Poole 1994). The newer techniques, eg kernel methods (Worton 1989), are more suited to analysis of home range use rather than to estimate range size (Harris et al. 1990). However, we have used kernel method (with 95\% of locations) to exclude possible outliers, in the cases when a number of locations was large enough. Individuals located more than 40 times were taken for home range calculation. For estimating $100 \%$ MCP home ranges we used one location per day if the lynx was stationary and two localizations if it moved farther than $2 \mathrm{~km}$ during 24 hours. For kernel estimation we tested the independence of locations by Schoener index. Testing showed that only one location could be taken if the lynx stayed several days in one place, and even few locations per day can be included if the lynx moved.

Most of the calculations were made according to the division of monitored animals into four groups: (1) adult males (body mass $\geq 19 \mathrm{~kg}$ ), (2) adult females (only females with kittens), (3) subadult males of known age $\leq 2.5$ years (Kvam 1991) or body mass $\leq 15 \mathrm{~kg}$, and (4) subadult females less than 2 years old (Kvam 1991) or weighing up to $15 \mathrm{~kg}$ and not accompanied by kittens. In two cases it was impossible to classify individuals precisely. A female Tamara was classified as an adult without young, as she had lost a 7-day old kitten. A female Sonia was treated as a subadult (during the first 15 months of tracking) and then as an adult when she gave birth to kittens in the second year of tracking.

Seasonal changes in the home range size were calculated for the autumn-winter ( 1 October to 30 April) and the spring-summer seasons (1 May to 30 September), and also in bimonthly periods. We followed the bimonthly changes in different periods for males and females (in males beginning from mating season in February-March, whereas in females beginning from the first two months after parturition - May-June). We assumed that different reproductive events are important for males and females. Percentage change of home range size in bimonthly periods was calculated in relation to October-November in males and November-December in females, because these periods had the least influence on reproductive behaviour in lynx. For analysis of seasonal changes in size of the home range we have used $100 \%$ MCP only, because samples of data were small.

We have delimited home ranges in 5-month intervals for 9 individuals. The arithmetic centers of such sub-ranges were then calculated and the straight-line distance between consecutive centers were measured to evaluate the temporal shifts of the lynx ranges. All calculations of home range size, its dynamies and independence of locations were made with the program "Tracker" (A. Angerbjörn, Radio Location System AB, Huddinge, Sweden).

Overlap of home ranges was estimated by two methods. We used the program "Tracker" to calculate a direct overlap between pairs of $100 \%$ MCP ranges of particular lynx. In order to exclude accidental factors (eg effect of the state border, sample size) which might affect the actual overlap, we have calculated a mean overlap in different groups of lynx (among adult males, adult females and between males and females) based on mapping of all radio-tracked and snow-tracked lynx (see maps in Jędrzejewski et al. 1996). The mean overlap in a particular group of lynx was calculated according to the following formula:

$$
\text { Oup }=(1-100 / D \times H R) \times 100,
$$

where: Ovp - mean percentage overlap in a particular group of lynx; $H R$ - the average winter home range in a given group (110 km for males, $93 \mathrm{~km}$ for females, and $101.5 \mathrm{~km}$ average for both sexes) (Jędrzejewski et al. 1996); D - density of the lynx group calculated from average winter densities of all lynx in BPF (5.0 ind. $/ 100 \mathrm{~km}^{2}$ ) and percentage of adult males (29\%) and females (23\%) in the population (Jędrzejewski et al. 1996).

\section{Sociality}

Frequency of social contact was estimated by measuring the straight distance between lynx located on the same day. In most cases, these locations were not simultaneous, because it took up to several hours from locating one lynx to finding another one. However, in the case of long distances between lynx the error was not significant, whereas in the case of shorter distances between lynx it was possible to locate them quickly. If two lynxes were suspected to be together, we took more than 
3 azimuths that differed by $45-135^{\circ}$ to ascertain if the bearings of both animals were the same. If possible, such places were later checked by snow-tracking. We have collected a total of 381 observations when at least two animals were located on the same day.

\section{Results}

\section{Home range size and its seasonal variation}

Area utilized by lynx grew with increasing numbers of localizations (Fig. 1). In females estimated home range size increased continuously and evenly during the whole period of tracking. Males (both adult and subadult) were characterized by a rapid growth of utilized area during the first 3 to 5 months of radio-tracking, and then the increase slowed. In several cases, however, home range size continued to enlarge throughout the whole period of monitoring. The life-time (ie calculated for the entire period of radio-tracking) home range size of adult females were 74 to 147 $\mathrm{km}^{2}$ (Table 1). Home range size of adult males ranged from 190 to $343 \mathrm{~km}^{2}$, and those of subadult males were 134 and 264 $\mathrm{km}^{2}$. Two subadult females utilized the ranges of 51 and $119 \mathrm{~km}^{2}$ (Table 1).

The life-time home range of adult males estimated by kernel method averaged 235 $\mathrm{km}^{2}$. The kernel life-time range for adult females was slightly larger than that estimated as MCP (Table 1). Males appeared to hold larger areas than females $(46 \%$ larger in MCP: $U=15.0, p<0.005$, Mann-Whitney $U$-test; and $35 \%$ larger in kernel method: $U=14.0, p=0.05$ ).

To assess the influence of radio-tracking time and other factors on the size of home range, we conducted the multiple regression analysis that included the following independent variables: sex of a lynx, number of localizations, time of monitoring, age, and body mass. All these factors explained $73 \%$ of variation in the size of lynx home range $(n=11, p<0.001)$. Semipartial correlations calculated for

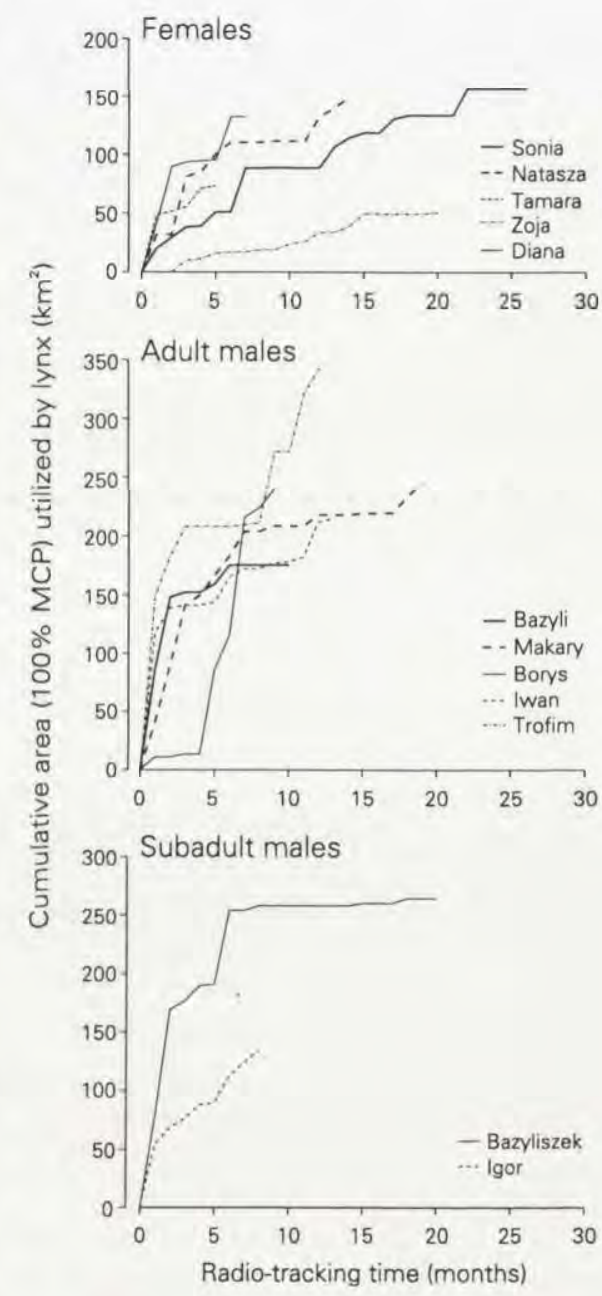

Fig. 1. Cumulative areas (Minimum Convex Polygon with $100 \%$ locations) utilized by radio-tracked lynx in Białowieża Primeval Forest in 1991-1996. 
Table 1. Sizes of seasonal and life-time home ranges of Eurasian lynx calculated by Minimum Convex Polygon with $100 \%$ locations and kernel method (95\% locations, for life-time range only) (auiumn-winter: 1 October - 30 April, and spring-summer: 1 May - 30 September). Number of locations in parentheses. ${ }^{a}$ Home range estimate based on locations of Bazyliszek, a dependent kitten of this female. ${ }^{b}$ Home range estimate based on locations of Lena, a dependent kitten of Diana. ${ }^{\mathrm{c}}$ Diana did not reproduce in the following spring, so this value was not taken for calculation of mean home range in spring-summer. ${ }^{\mathrm{d}}$ Tamara, as an adult without kittens, was not included in calculations of average home range size. ${ }^{e}$ Kernel home ranges are overestimated due to high dispersion of locations.

\begin{tabular}{|c|c|c|c|c|c|c|}
\hline \multirow{2}{*}{ Lynx } & \multicolumn{4}{|c|}{ Seasonal home range (100\% MCP) } & \multicolumn{2}{|c|}{$\begin{array}{l}\text { Life-time home ranges } \\
\qquad\left(\mathrm{km}^{2}\right)\end{array}$} \\
\hline & $\begin{array}{l}\text { Autumn- } \\
\text { winter }\end{array}$ & $\begin{array}{l}\text { Size } \\
\left(\mathrm{km}^{2}\right)\end{array}$ & $\begin{array}{l}\text { Spring- } \\
\text { summer }\end{array}$ & $\begin{array}{c}\text { Size } \\
\left(\mathrm{km}^{2}\right)\end{array}$ & $100 \% \mathrm{MCP}$ & $95 \%$ kernel \\
\hline \multicolumn{7}{|c|}{ Adult males } \\
\hline Bazyli & $1990 / 91$ & $148(30)$ & 1991 & $135(46)$ & $222(101)$ & 217 (93) \\
\hline Makary & & & & & $246(197)$ & $236(139)$ \\
\hline Borys & & & 1992 & $195(32)$ & $240 \quad(59)$ & $283 \quad(43)$ \\
\hline Iwan & $\begin{array}{l}1994 / 95 \\
1995 / 96\end{array}$ & $\begin{array}{r}139(47) \\
95(86)\end{array}$ & 1995 & $102(82)$ & $190(215)$ & $158(154)$ \\
\hline Trofim & $\begin{array}{l}1994 / 95 \\
1995 / 96\end{array}$ & $\begin{array}{l}149(55) \\
296(89)\end{array}$ & 1995 & $140(92)$ & $343(241)$ & 283 (194) \\
\hline Mean \pm SD & & $165 \pm 76$ & & $143 \pm 38$ & $248 \pm 57$ & $235 \pm 52$ \\
\hline \multicolumn{7}{|c|}{ Adult females } \\
\hline Bazyliszek's mother $^{a}$ & $1991 / 92$ & $99(38)$ & & & & \\
\hline Natasza & $\begin{array}{l}1992 / 93 \\
1993 / 94\end{array}$ & $\begin{array}{l}82(67) \\
98(55)\end{array}$ & 1993 & $60(70)$ & $147(173)$ & $147(104)$ \\
\hline Sonia & $1994 / 95$ & $101(96)$ & 1994 & $49(136)$ & $124(235)$ & $118(116)$ \\
\hline Diana & $1994 / 95$ & $90^{\mathrm{b}}(37)$ & 1995 & $96^{\mathrm{c}}(39)$ & $129(79)$ & $192^{\mathrm{e}}(53)$ \\
\hline Tamara & & & 1994 & $67^{\mathrm{d}}(77)$ & $74^{\mathrm{d}}(117)$ & \\
\hline Mean \pm SD & & $94 \pm 8$ & & $55 \pm 8$ & $133 \pm 12$ & $152 \pm 37$ \\
\hline \multicolumn{7}{|c|}{ Subadult males } \\
\hline Bazyliszek & $1992 / 93$ & $55(32)$ & 1993 & $60 \quad(20)$ & $264(177)$ & $427^{\mathrm{e}}(99)$ \\
\hline Igor & $1994 / 95$ & $73(45)$ & 1994 & 73 (85) & $134(145)$ & $193^{\mathrm{e}}(98)$ \\
\hline Mean \pm SD & & $64 \pm 13$ & & $67 \pm 9$ & $199 \pm 92$ & $310 \pm 165$ \\
\hline \multicolumn{7}{|c|}{ Subadult females } \\
\hline Sonia & $1992 / 93$ & $39(60)$ & 1993 & $71 \quad(57)$ & & \\
\hline & $1993 / 94$ & $108(156)$ & & & $119(273)$ & $124(167)$ \\
\hline Zoja & $1993 / 94$ & $47 \quad(26)$ & & & $51 \quad(59)$ & 66 (43) \\
\hline Mean \pm SD & & $65 \pm 38$ & & & $85 \pm 48$ & $95 \pm 41$ \\
\hline
\end{tabular}

each of the variables showed that sex of lynx was most important $\left(s r^{2}=0.18\right)$, following by time of monitoring $\left(s r^{2}=0.03\right)$, and number of localizations 
$\left(s r^{2}=0.02\right)$. Body mass and age of the lynx contributed very little to the total variation explained $\left(s r^{2}=0.007\right.$ and 0.006 , respectively). If only sex and number of localiza- tions were taken as independent variables, the value of $R^{2}$ remained very high $\left(R^{2}=0.7, p<0.001, n=11\right)$ with the sex being the most important factor in the variation of lynx home range size $\left(s r^{2}=0.55\right)$.

When the sample size was adequate, we calculated the size of lynx home ranges in the spring-summer and autumn-winter seasons. The distribution of radio-tracked lynx home ranges in Białowieża Forest is shown in Fig. 2. All lynx monitored in a given period (including those, which due to small sample of locations were not used in calculations) are marked. In the autumn-winter season mean size of adult male home range was $165 \mathrm{~km}^{2}$ (Table 1). Adult females occupied ranges $43 \%$ smaller than those of adult males $(U=22, p<0.05$; Table 1$)$. The home ranges of subadult males $(n=2)$ were similar in size to those of subadult females (mean $65 \mathrm{~km}^{2}$; Table 1). Autumn-winter home ranges of subadult females were, on average $30 \%$ smaller than those of adult females, but the difference was not significant $(U=10.0, p>0.1$; Table 1 ).

Adult male ranges (mean $143 \mathrm{~km}^{2}, n=2$ ) in spring-summer, were $61 \%$ larger than those of adult females (Table 1). Because we did not find statistical differences between the autumn-winter and spring-summer ranges of adult males, we compared the ranges of adult versus subadult males in the two seasons pooled. Subadult males appeared to hold significantly smaller ranges than adults $(U=44.0, p<0.005)$.

Adult male lynx showed no difference in the size of home range between autumn-winter and spring-summer seasons $(U=12.0, p>0.1$; Table 1, Fig. 2). Unlike in males, the autumn-winter ranges of adult females were almost twice as large as those in spring-summer, but the number of spring-summer home ranges $(n=2)$ made the statistical analysis impossible. Home ranges of subadult males did not appear to change between the autumn-winter and the spring-summer periods, although again the sample was too small for statistical comparison.

Bimonthly changes in home range sizes were analysed in order to relate the size of area utilized to reproductive status of lynx. In adult males, a notable growth in the area utilized was found in December-January, ie the pre-mating season (by $94 \%$ compared to October-November range) and February-March, ie the mating season (by $36 \%)(G$-test, $p<0.005$; Fig. 3).

In contrast to adult males, subadult males showed a $51 \%$ decrease in the sizes of their home ranges in June-July period (Fig. 3). Bimonthly changes of the home range size in subadult males were significantly different than those in adult males (replicated goodness of fit test, $G=18.22, p<0.001$ ). However, there were no data for subadults in December-March, when the increase of the adults' home range was largest.

In reproducing adult females the most conspicuous change occurred in May-June, when the area utilized decreased by $81 \%$ in comparison to November-December. Female home ranges were largest in January-February (39\% 

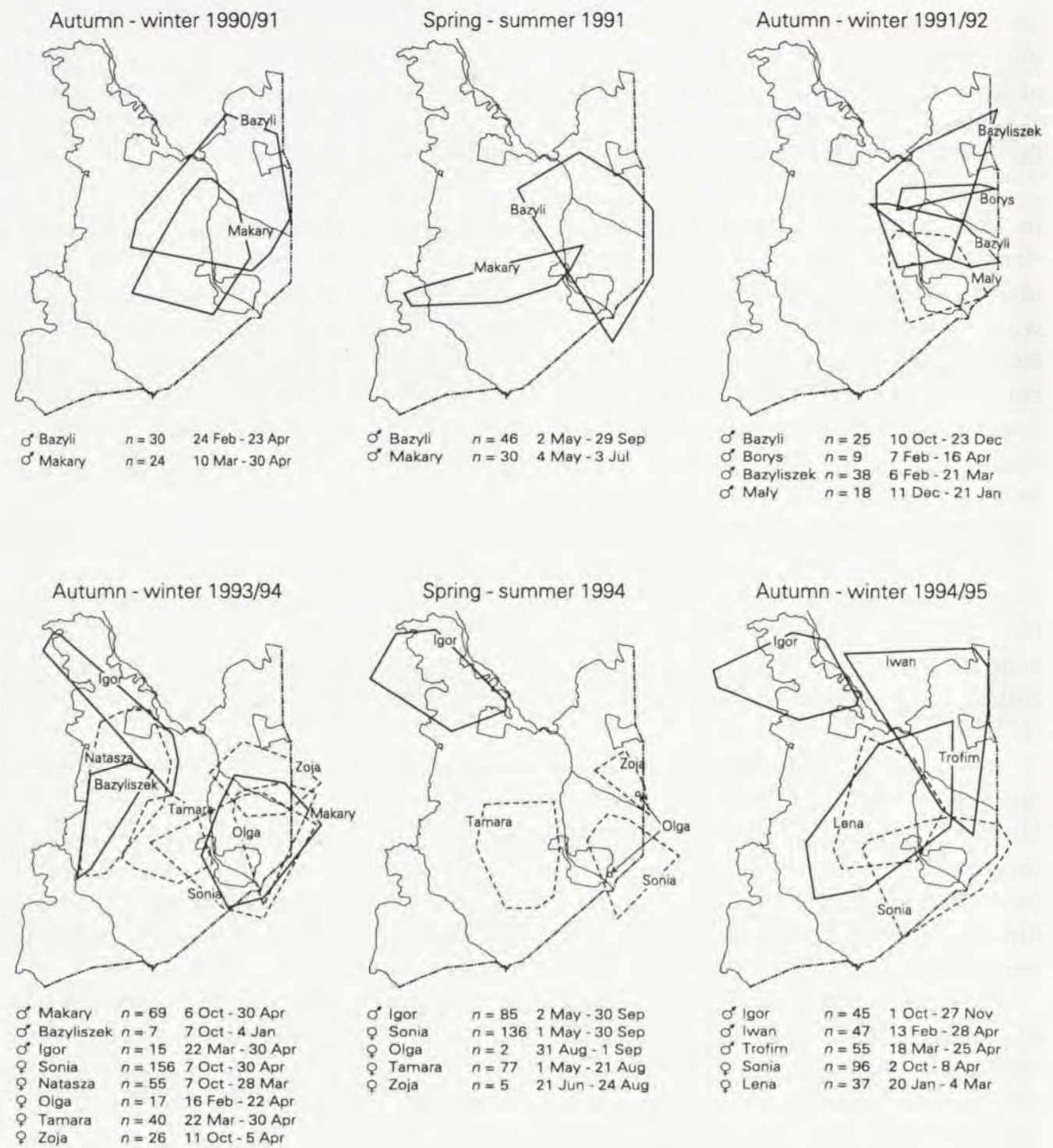

Fig. 2. Spatial distribution of home ranges of lynx monitored in BPF in autumn-winter (1 October -tracked lynx are shown, including those not taken for calculations of home range size due to

increase; Fig. 3). Bimonthly changes of home ranges of adult females raising kittens were particularly visible as compared with single females $(n=2$, a subadult and an adult without kittens; replicated goodness of fit test, $G=39.4, p<0.001$ ). 


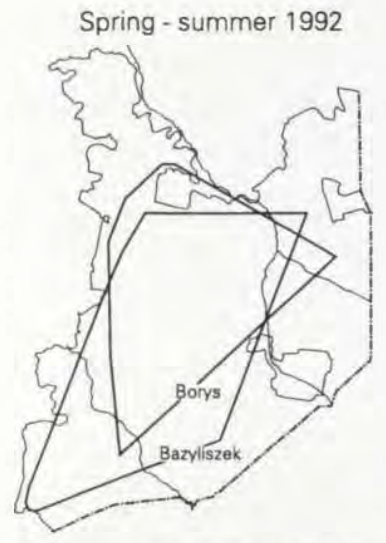

6 Borys $n=32 \quad 1$ May-15 Sep Of Bazyliszek $n=89 \quad 2$ May -25 Sep

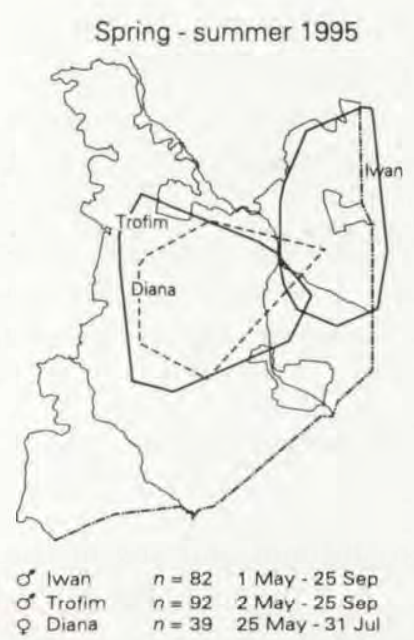

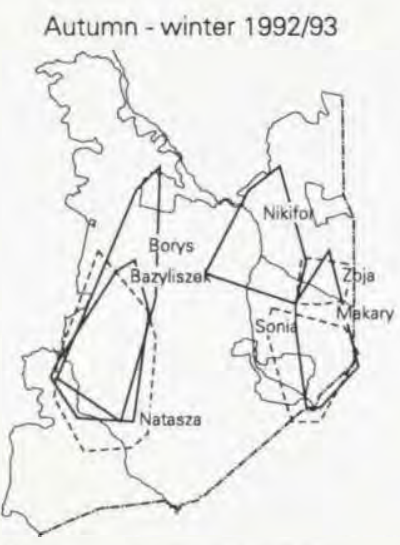

0 Borys $\quad n=18 \quad 5$ Oct $-7 \mathrm{Dec}$ 6 Makary $n=33 \quad 27 \mathrm{Mar}-30 \mathrm{Apr}$ 0 Bazyliszek $n=32 \quad 18$ Oct-30 Apr O Nikifor $n=15$ 25 Jan-23 Feb Q Sonia $n=60$ 31 Jan-30 Ap Natasza $n=48 \quad 4$ Feb-30 Apr

$\begin{array}{lll}\text { Noja } & n=48 & 5 \mathrm{Jan}-7 \mathrm{Apr}\end{array}$

Autumn - winter 1995/96

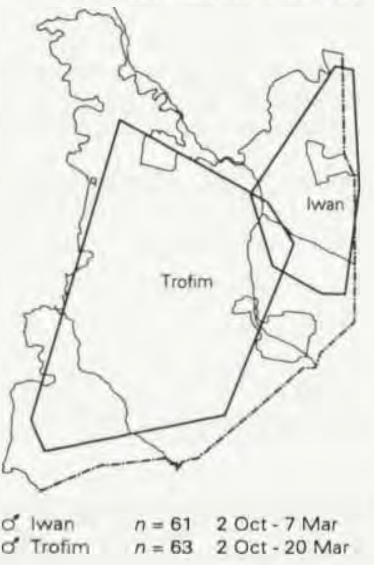

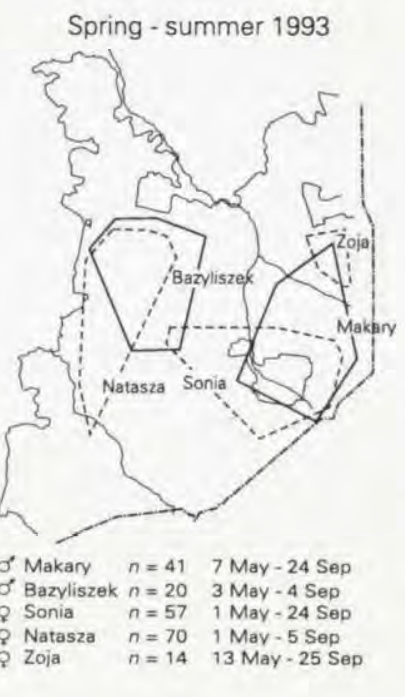

$\begin{array}{lllll}0 & 5 & 10 & 15 & 20\end{array}$

state border

\{ edge of Bialowieża Forest

- home ranges of male lynx

.... home ranges of female lynx

$n$ - number of locations in a given season

5 Jan - 7 Apr - terms of radio-tracking of a given lynx

30 April) and spring-summer (1 May - 30 September) seasons from 1990/91 to 1995/96. All radioinsufficient sample of locations.

\section{Home range shifts during a lynx's life}

The fidelity of the lynx to particular areas appeared to be fairly low. The average shift of the arithmetic centers of 5-month sub-ranges was $4.0 \mathrm{~km}$ in adult males, $2.7 \mathrm{~km}$ in adult females and $4.7 \mathrm{~km}$ in subadult males (Table 2, Fig. 4). Differences 


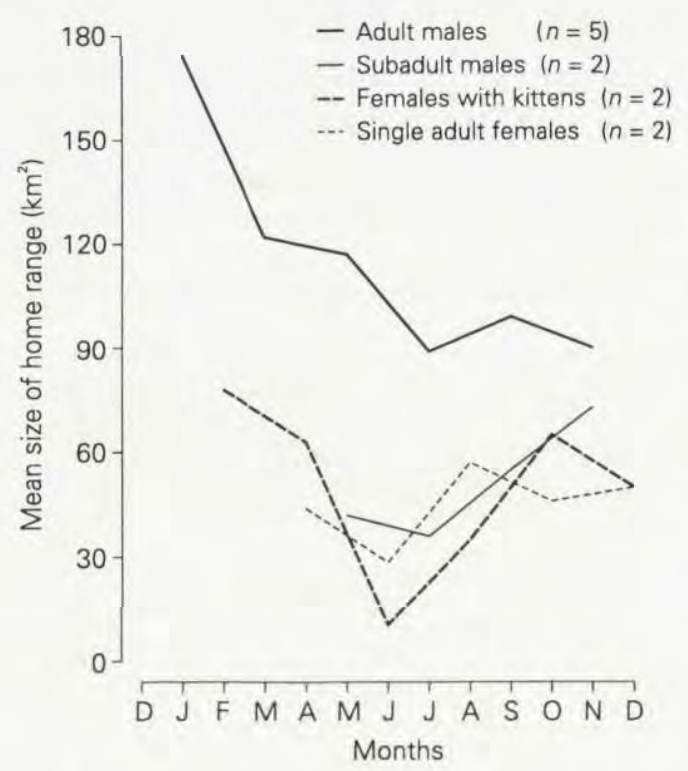

Fig. 3. Bimonthly changes of the mean size of lynx home range. Only samples with $\geq 20$ localizations per each two-month period were taken. between various age/sex groups of lynx were not significant (Mann-Whitney $U$-test, $p>0.1$ ), but the females' ranges seem to be most stable. Home range of female Sonia, a subadult during the first year of monitoring, shifted very little during the whole monitoring period of 26 months ( $1.8 \mathrm{~km}$, on average; Table 2 , Fig. 4).

In some cases, it was possible to associate the observed shift with some events in the lynx's life. For instance, the $8.7 \mathrm{~km}$ shift of Makary's range coincided with the death of an adjacent resident male, Bazyli. Makary's range moved eastward and it covered the area of Bazyli's former range (Fig. 4). The $7.3 \mathrm{~km}$ shift of the arithmetic center of Natasza's home range may be related to the fact that during the last period of monitoring she lost her litter for unknown reasons. Thus, her status as a breeding female changed and another adult female accompanied by two kittens was recorded by snow-tracking inside Natasza's former range.

\section{Home range overlap}

Home range overlap among lynx depended mainly on the age and sex of the individuals involved. The average direct overlap of home range among males radio-tracked simultaneously was $30 \%$ (Table 3, Fig. 5). The overlap estimated indirectly from densities and spatial structure of the population (see Material and methods) was $37 \%$. There was extensive overlap $(75 \%)$ between the home ranges of adult and subadult males (Borys and Bazyliszek, Fig. 5, Table 3). Interestingly, after the death of an adult lynx Borys, the subadult Bazyliszek stayed in the range covering $79 \%$ of the former Borys's range during the last five months of tracking (Fig. 5, cf Fig. 4).

Indirect method of calculating overlap among adult females yielded an estimate of $6 \%$. Overlap between pairs of radio-tracked adult and subadult females varied from 0 to $73 \%$ (Table 3, Fig. 5), and was on average $29 \%$. It must be noted, however, that the most extensive overlaps (eg $73 \%$ in the pair Olga and Sonia) could have been an overestimate, because a female Olga was located only 19 times and the 
Table 2. The shifts of lynx home ranges as revealed by straight-line distances (in $\mathrm{km}$ ) between arithmetic centers of ranges calculated for 5 -month periods. ${ }^{a}$ The transmitter failed after 4 months, and then was replaced 1.5 year later.

\begin{tabular}{|c|c|c|c|c|c|c|}
\hline \multirow[t]{2}{*}{ Lynx } & \multicolumn{6}{|c|}{$\begin{array}{l}\text { Distance }(\mathrm{km}) \text { after a given period } \\
\text { of radio-tracking (in months) }\end{array}$} \\
\hline & 5 & 10 & 15 & 20 & 25 & 30 \\
\hline \multicolumn{7}{|c|}{ Adult males } \\
\hline Bazyli & 3.1 & & & & & \\
\hline \multirow[t]{3}{*}{ Makary } & $-{ }^{\mathrm{a}}$ & $-{ }^{a}$ & $-{ }^{a}$ & 8.7 & 7.5 & 7.6 \\
\hline & 1.5 & & & & & \\
\hline & 0.2 & & & & & \\
\hline Borys & 11.9 & & & & & \\
\hline Iwan & 4.3 & & & & & \\
\hline Trofim & 2.9 & & & & & \\
\hline \multirow[t]{2}{*}{ Mean \pm SD } & $4.0 \pm 4.1$ & & & & & \\
\hline & & emal & & & & \\
\hline \multirow[t]{4}{*}{ Sonia } & 2.9 & 1.3 & 1.2 & 1.3 & & \\
\hline & 2.5 & & & & & \\
\hline & 1.4 & & & & & \\
\hline & 2.0 & & & & & \\
\hline \multirow[t]{2}{*}{ Natasza } & 3.0 & 7.3 & & & & \\
\hline & 4,4 & & & & & \\
\hline \multirow[t]{2}{*}{ Mean \pm SD } & $2.7 \pm 1.0$ & & & & & \\
\hline & Subad & dult $r_{1}$ & nales & & & \\
\hline \multirow[t]{2}{*}{ Bazyliszek } & 4.1 & 3.9 & & & & \\
\hline & 7.7 & & & & & \\
\hline Igor & 2.4 & & & & & \\
\hline Mean \pm SD & $4.7 \pm 2.7$ & & & & & \\
\hline
\end{tabular}

Table 3. Home range overlaps between pairs of radio-tracked lynx as calculated by MCP at $100 \%$ level and kernel method at 95\% level (kernel method was used for large enough samples of locations). Numbers are percentages of areas of home ranges of the first listed lynx covered by the range of the second lynx.

\begin{tabular}{cc}
\hline Pairs of lynx & $\begin{array}{c}\text { Percentage overlaps of } \\
\text { home ranges }\end{array}$ \\
\cline { 2 - 3 } & $100 \%$ MCP $95 \%$ kernel \\
\hline
\end{tabular}

\begin{tabular}{lcc} 
& Adult males & \\
Bazyli $\times$ Makary & 42 & - \\
Makary $\times$ Bazyli & 42 & - \\
Iwan $\times$ Trofim & 21 & 26 \\
Trofim $\times$ Iwan & 14 & 20 \\
\multicolumn{2}{c}{ Adult male and subadult male } \\
Borys $\times$ Bazyliszek & 81 & 84 \\
Bazyliszek $\times$ Borys & 69 & 89
\end{tabular}

\begin{tabular}{lcc} 
& Adult females \\
Sonia $\times$ Olga & 50 & - \\
Olga $\times$ Sonia & 73 & - \\
Zoja $\times$ Olga & 33 & - \\
Olga $\times$ Zoja & 22 & - \\
Sonia $\times$ Tamara & 0 & 0 \\
\multicolumn{4}{c}{ Subadult females } \\
Sonia $\times$ Zoja & 6 & 10 \\
Zoja $\times$ Sonia & 17 & 20 \\
\multicolumn{1}{c}{ Males and females } & \\
Makary $\times$ Sonia & 78 & 78 \\
Sonia $\times$ Makary & 65 & 78 \\
Makary $\times$ Zoja & 27 & 30 \\
Zoja $\times$ Makary & 54 & 50 \\
Makary $\times$ Olga & 49 & - \\
Olga $\times$ Makary & 95 & - \\
Trofim $\times$ Diana & 28 & - \\
Diana $\times$ Trofim & 99 & - \\
Iwan $\times$ Diana & 7 & - \\
Diana $\times$ Iwan & 14 & - \\
Bazyliszek $\times$ Natasza & 80 & 89 \\
Natasza $\times$ Bazyliszek & 83 & 96 \\
& &
\end{tabular}

largest portion of her home range was probably in Belarus. If she is excluded, mean overlap between remaining pairs of radio-tracked females was $8 \%$. 

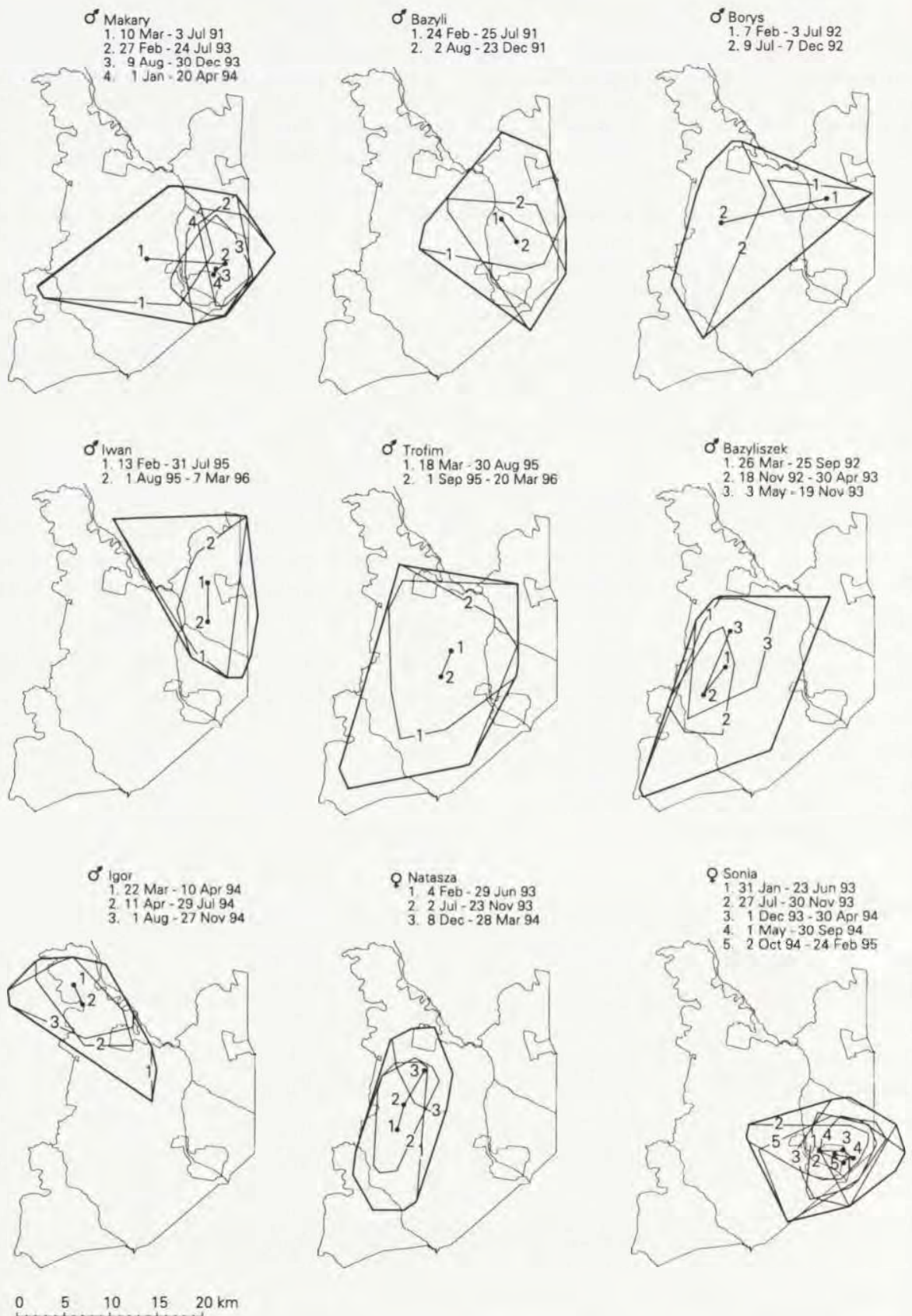

!. 2 shifts of home range arithmetic centers, -1- 5 - month home range ,

life-time home range

Fig. 4. Shifts of lynx home ranges calculated for 5-month intervals. Dots are arithmetic centers of the 5 -month ranges. Numbers of home ranges correspond to numbers of their arithmetic centers. 

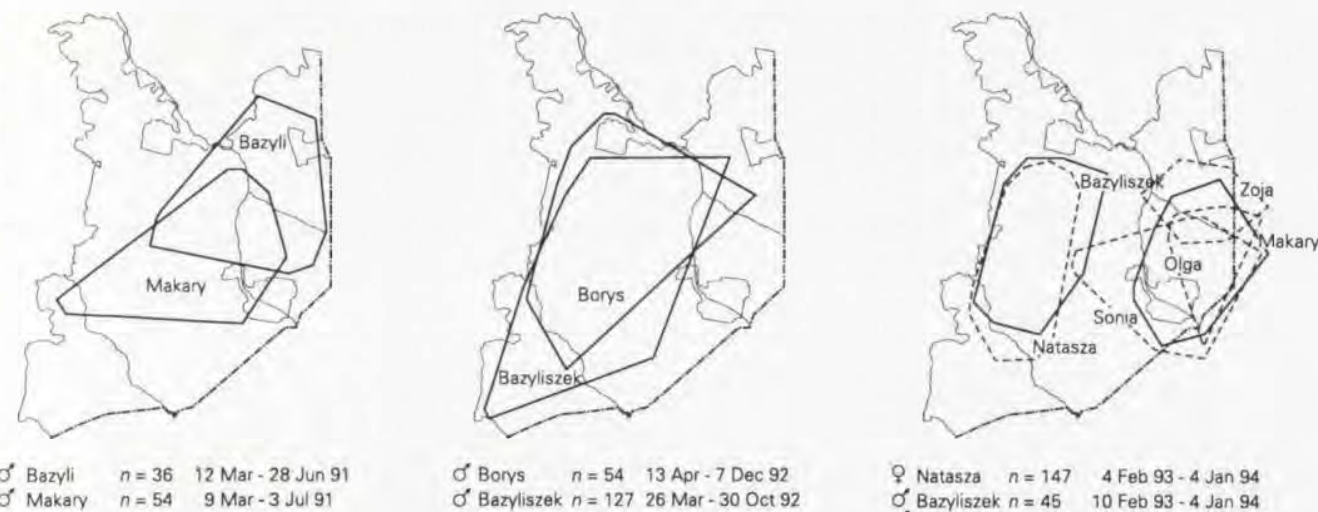

of Makary $n=54 \quad 9$ Mar-3 Jul 91

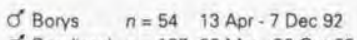

Q Natasza $n=147 \quad 4$ Feb $93-4$ Jan 94

Ó. Bazyliszek $n=45 \quad 10$ Feb $93-4$ Jan 94

Oakary $n=143 \quad 27$ Feb $93-20$ Apr 94

\begin{tabular}{ll}
$n=258$ & $27 \mathrm{Feb} 93.30$ Apr 94 \\
\hline & $n=52$
\end{tabular}

$\begin{array}{lll} & n=52 & 6 \text { Mar } 93-5 \text { Apr } 94 \\ \text { Olga } & n=19 & 16 \text { Feb } 94-1 \text { Sep } 94\end{array}$
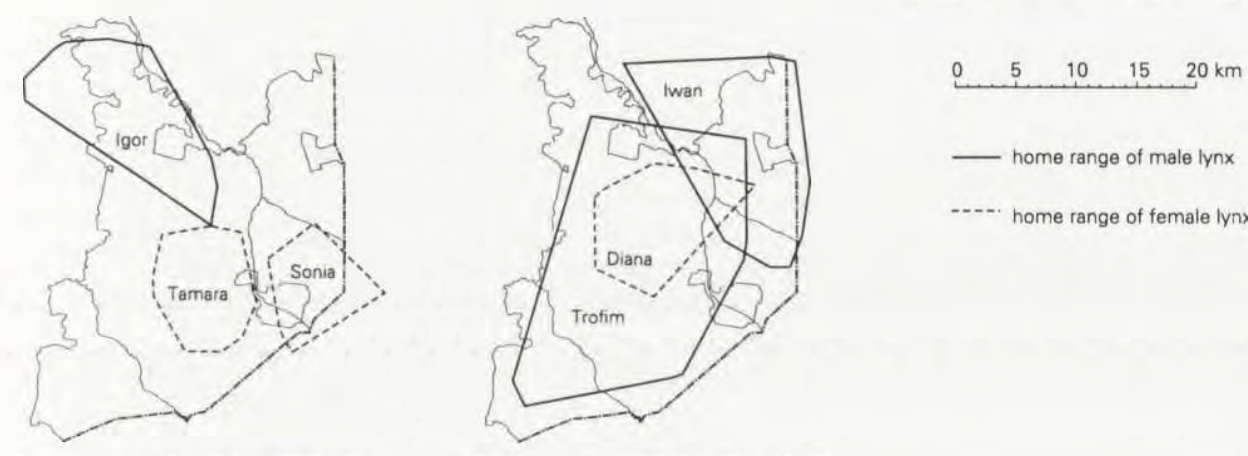

$\sigma$ I wan $n=19020$ Mar $95-1$ Mar 96

6 Trofim $n=21018$ Mar $95-1$ Mar 96

Tamara $n=11729$ Mar -21 Aug 94

Q Diana $n=41 \quad 26$ May $95-31$ Jul 95

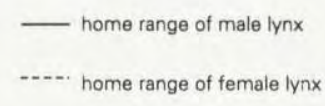

Fig. 5. Home range overlaps of lynx that were radio-tracked at the same time for at least 4 months. Explanations of symbols as in Fig. 2.

The average overlap among males and females, as estimated indirectly, was $62 \%$. The mean overlap between pairs of radio-tracked lynx was $57 \%$ (Table 3 , Fig. 5). However, if we exclude a pair Iwan and Diana with peripheral overlap $(7-14 \%)$, this value would increase to $66 \%$.

\section{Distances among individual lynx as a measure of sociality}

Except for females with dependent kittens, the lynx usually avoided contact with conspecifics (Fig. 6, Tables 4 and 5). The avoidance was most conspicuous among adult males which were always found $>1 \mathrm{~km}$ away from each other. The average distance between simultaneously radio-tracked males was $11.6 \mathrm{~km}$ (Tables 4 and 5, Fig. 6). 


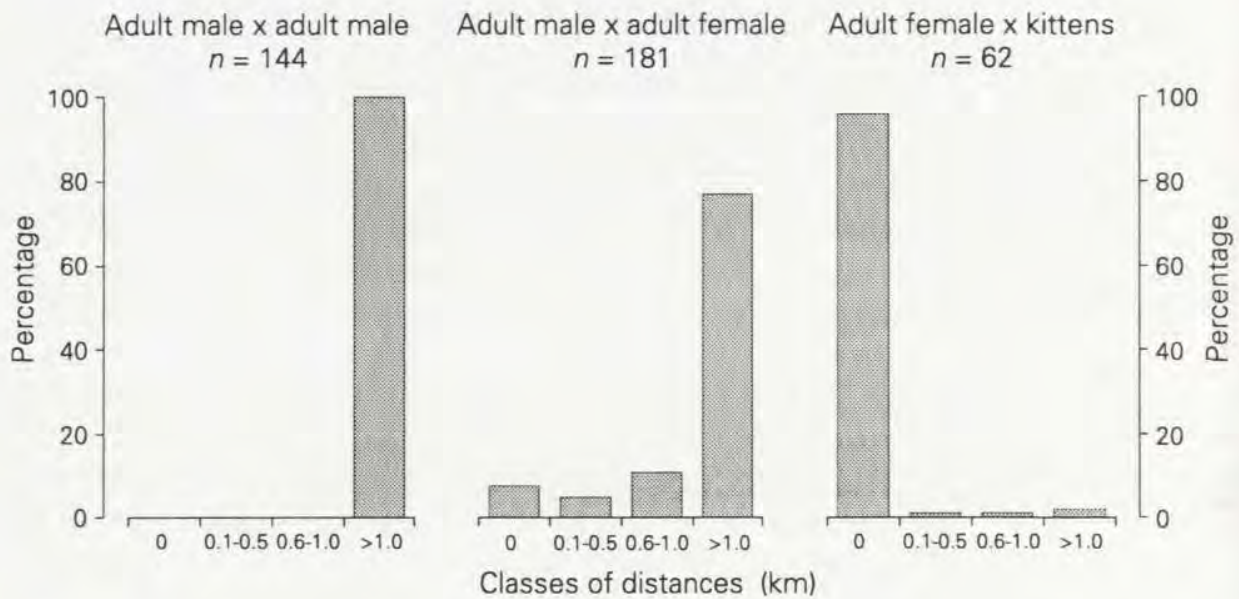

Fig. 6. Frequency distribution of linear distances (in $\mathrm{km}$ ) between simultaneous locations of radio-tracked lynx. Distances between males and between males and females were shown according to data in Table 4; distances between a female and her dependent kittens are based on data shown in Table 5 .

Table 4. Linear distances between simultaneous locations of lynx $(\mathrm{km})$. Significance of differences among groups of lynx (males-males, females-females, males-females) was tested with Kruskal-Wallis one-way analysis of variance $\left(\chi^{2}=106.3, p<0.005\right) .{ }^{a}$ Sample not taken for analysis due to small size. $n-$ number of locations.

\begin{tabular}{|c|c|c|c|}
\hline \multirow{2}{*}{ Pair of lynx } & \multicolumn{3}{|c|}{ Distances between locations $(\mathrm{km})$} \\
\hline & $n$ & Mean \pm SD & Range \\
\hline \multicolumn{4}{|c|}{ Adult males } \\
\hline Makary $\times$ Bazyli & 13 & $8.2 \pm 6.2$ & $1.8-22.8$ \\
\hline Iwan $\times$ Trofim & 131 & $11.7 \pm 5.5$ & $1.0-27.7$ \\
\hline Mean \pm SD & 144 & $11.6 \pm 5.5$ & \\
\hline \multicolumn{4}{|c|}{ Females } \\
\hline Sonia $\times$ Zoja & 32 & $8.8 \pm 3.2$ & $2.7-15.4$ \\
\hline Olga $\times$ Sonia & 11 & $6.3 \pm 3.3$ & $0.5-11.5$ \\
\hline Mean \pm SD & 43 & $8.1 \pm 3.4$ & \\
\hline \multicolumn{4}{|c|}{ Males and females } \\
\hline Makary $\times$ Sonia & 96 & $3.8 \pm 2.9$ & $0-13.3$ \\
\hline Makary $\times$ Zoja & 23 & $6.1 \pm 4.2$ & $0-13.7$ \\
\hline Natasza $\times$ Bazyliszek & 36 & $3.8 \pm 3.6$ & $0-14.1$ \\
\hline Diana $\times$ Trofim & 26 & $6.5 \pm 3.0$ & $1.0-14.7$ \\
\hline Mean \pm SD & 181 & $4.4 \pm 3.5$ & \\
\hline \multicolumn{4}{|c|}{ Adult male and subadult male ${ }^{a}$} \\
\hline Borys $\times$ Bazyliszek & 14 & $5.5 \pm 4.9$ & $0-15.4$ \\
\hline
\end{tabular}


The average distance between females $(8.1 \mathrm{~km}$, Table 4$)$ was shorter and the frequency distribution of distances were significantly different than those in males (Kolmogorov-Smirnov two sample test, $D=0.356, p=0.002$ ), but no females were found together. The nearest location of two females was $0.5 \mathrm{~km}$ apart. There was a unique case when females Olga and Sonia and two other lynx were found close to each other during the mating season (see below).

The strongest tendency to consort with each other was between males and females (Fig. 6; $G$-test for homogeneity of percentages, $G=35, p<0.001$ ). The average distance between male and female $(4.4 \mathrm{~km}$, Table 4$)$ was shorter and the frequency distribution of distances were significantly different from those in male-male and female-female pairs (Kolmogorov-Smirnov two sample test, $D=$ 0.588 and 0.475 , respectively, $p<0.005$ ). Several times we located a male and a female actually together or within $1 \mathrm{~km}$ of each other in various seasons (Table 5), and not only in the mating season occuring from mid February to late March. We have no data about the actual time the lynx spent together or stayed within $1 \mathrm{~km}$ of each other. Nonetheless, we found no remarkable seasonal differences in the number of days when such meetings were recorded. The male Makary was found near or with a female on one to five days during the presumed mating season, and on two to three days during the other months.

Moreover, we recorded four cases of sharing the same kill by male Makary and a female (Sonia or Zoja) during as well as outside the mating season (Table 5). In one of these cases (25-26 April 1993) there were two roe deer killed within $200 \mathrm{~m}$ of each other. Both were killed by the female and the male appeared there 3 days later. During 2 days when lynx stayed near the kills, they were localized together at the kill site on the first night, for half an hour only. On the following night, when the male fed on one of the kills, the female stayed 500 meters apart. The female came to feed 30 minutes later, after the male had left the kill.

Tracks on snow left by two other lynx gave the idea about possible inter-actions between males and females during their contacts. On 19 November 1993, an adult female Natasza with two kittens and a male Bazyliszek (about 2.5 yrs old) met on the forest road. Snow trodden by the lynxes, small tufts of lynx hair, and drops of the blood were later found in that place. The lynx moved from this place in the opposite directions.

During the mating season, we recorded an adult male with three females staying near each other. On 17 February 1994 a male Makary and an adult female Olga were located together. On the following day, near that place we found an area of $500 \mathrm{~m}^{2}$, densely covered with shrubs and fallen trees, with numerous fresh tracks of more than two individuals. On 18 February, Makary and Olga were 0.7-1 km away from each other, while another female Sonia came to the same area. She was found at a distance of $0.8 \mathrm{~km}$ from Makary and $0.5 \mathrm{~km}$ from Olga. On 19 February, Makary and Olga remained within $1 \mathrm{~km}$ from each other, female Sonia disappeared, and yet another female Zoja came and was recorded $1.5 \mathrm{~km}$ 
Table 5. Frequency distribution of the distances between lynx with overlapping home ranges in particular sex/age groups of lynx as recorded by radio-tracking. ${ }^{\text {a }}$ These cases include 4 meetings of a male Makary with females at the kill: roe and red deer (twice with Sonia and twice with Zoja). Classes of distances $\leq 1 \mathrm{~km}$ that were not recorded in adult male $\times$ adult male and female $\times$ female groups, are not listed. A female Olga was not included in this table as most of her locations were in February.

\begin{tabular}{|c|c|c|c|c|c|c|c|c|c|c|c|c|c|}
\hline \multirow{2}{*}{$\begin{array}{l}\text { Distance } \\
(\mathrm{km})\end{array}$} & \multicolumn{12}{|c|}{ Numbers of locations in months } & \multirow{2}{*}{ Total } \\
\hline & $J$ & $\mathrm{~F}$ & M & A & M & $J$ & $\mathrm{~J}$ & A & $\mathrm{S}$ & $\mathrm{O}$ & $\mathrm{N}$ & $\mathrm{D}$ & \\
\hline \multicolumn{14}{|c|}{ Female $\times$ female $(2$ lyn $x)$} \\
\hline$>1$ & 4 & 4 & 8 & 4 & 2 & 4 & & & 3 & 1 & 2 & & 32 \\
\hline \multicolumn{14}{|c|}{ Adult male $\times$ adult male (4 lynx) } \\
\hline$>1$ & 17 & 9 & 14 & 21 & 19 & 12 & 8 & 9 & 6 & 9 & 4 & 16 & 144 \\
\hline \multicolumn{14}{|c|}{ Adult male $\times$ subadult male ( 2 lynx) } \\
\hline 0 & & & & & & & 1 & & & & & & 1 \\
\hline $0.1-0.5$ & & & & & & & & & & & & & 0 \\
\hline $0.6-1$ & & & & & & & 1 & & & & 1 & & 2 \\
\hline$>1$ & & 2 & 1 & 3 & & & 3 & & & & 2 & & 11 \\
\hline \multicolumn{14}{|c|}{ Male $\times$ female $(5$ lynx $)$} \\
\hline 0 & & 1 & $3^{\mathrm{a}}$ & $2^{\mathrm{a}}$ & & 1 & & & & & $4^{\mathrm{a}}$ & & 11 \\
\hline $0.1-0.5$ & & 1 & 1 & 2 & & 1 & & & 2 & 2 & & & 9 \\
\hline $0.6-1$ & 1 & 1 & 5 & 3 & 1 & 3 & 1 & & 1 & & 3 & 1 & 20 \\
\hline$>4$ & 1 & 4 & 14 & 24 & 14 & 28 & 13 & 4 & 8 & 5 & 15 & 11 & 141 \\
\hline \multicolumn{14}{|c|}{ Female $\times$ kittens (one family) } \\
\hline 0 & 14 & 4 & 14 & 2 & & & & & & & 10 & 14 & 58 \\
\hline $0.1-0.5$ & & 1 & & & & & & & & & & & 1 \\
\hline $0.6-1$ & 1 & & & & & & & & & & & & 1 \\
\hline$>1$ & & & & & & & & & & & & 2 & 2 \\
\hline
\end{tabular}

from Makary and Olga. On 20 February, all lynx were further than $4 \mathrm{~km}$ from each other.

Despite extensive overlap of ranges of an adult and a subadult male, they usually stayed far away of each other (5.5 km on average; Table 4). However, in one of 14 simultaneous locations these two males were found together (Table 5).

In contrary to male-male and male-female pairs of lynx $(G=257.6$ and 192.6 respectively, $p<0.001$ ), an adult female spent much time with her dependent kittens (Fig. 6, Table 5). However, the data cover the period from November till April only (Table 5), and this time does not include the period of low mobility of very small kittens, when the female has to leave the litter when hunting. 


\section{Discussion}

\section{Factors affecting home range size in the lynx population}

Increasing size of the lynx home ranges with longer radio-tracking time, indicated that the period needed to know the total area utilized by this cat is $>1$ year. This results from lynx's large home ranges and their spatial shifts. However, it does not greatly bias the obtained results. Our analysis of seasonal changes in lynx home ranges were not affected by the time of radio-tracking, as the comparisons were always made for the same time spans. The size of life-time home ranges of lynx, given in this paper, are actually minimal values. Probably, using more efficient methods of searching for radio-collared cats (location from the aircraft or satellite telemetry) would result in even larger values of home ranges and might decrease the time when home range growth reaches an asymptote.

The population of lynx analysed in this paper inhabited continuous woodland with relatively low human disturbance, and was located on the south-western limit of the species range. In this habitat, ungulates (roe and red deer) were prime prey of lynx (Jędrzejewski et al. 1993).

It has been documented (eg Goszczyński 1986), that a home range size in predators may be related to their foraging activity. Because female lynx with kittens in BPF were reported to kill 1.5 times (on average) more deer than adult males (Okarma et al. 1997), they would be expected to utilize larger areas than males, which are not contributing to raising kittens. The present study showed that males maintained larger home ranges than females in both autumn-winter and spring-summer season. What does really determine the size of home ranges in male and female lynx? In males, the increase of range size in pre-mating and mating season can be explained by searching for receptive females. Thus, the density of females seems to be a crucial factor shaping males' home ranges, especially, because male reproductive success is limited by number of matings a male can achieve (Parker 1978). In females, the decrease of range size after parturition, followed by its expansion till the next spring suggested that female range size was governed by mobility and increasing food requirements of young. Therefore, our study supports Sandell's (1989) suggestion that home range sizes of males and females in solitary predators are determined by different factors.

We had no opportunity to investigate the causes of the observed spatial shifts in lynx ranges. However, as suggested by two cases (males Makary and Bazyli), adult male lynx could shift their ranges in response to disappearance of a neighbouring resident individual. Males may then increase their reproductive success by expansion and shifts of their ranges to have access to more females. Adult females had higher site fidelity than males. This way they become more familiar with their ranges, which possibly improves their hunting success and consequently reproductive success. 
Spatial home range shifts in other solitary felids were found also by Seidensticker et al. (1973), Sunquist (1981), Rabinowitz and Nottingham (1986), and Lovallo and Anderson (1995). Anderson (1988) stated that bobcats maintain their home ranges until vacancies in higher quality areas are created by death of their tenants. In cougars, vacating male ranges were filled only by transient males (Laing and Lindzey 1993).

Besides our study, the only data on Eurasian lynx home range as studied by radio-telemetry come from reintroduced populations in western Europe (Haller and Breitenmoser 1986, Herrendschmidt et al. 1986, Breitenmoser et al. 1993). These authors have reported home ranges of $275-465 \mathrm{~km}^{2}$ (even $1860 \mathrm{~km}^{2}$ ) in males, and $96-337 \mathrm{~km}^{2}$ in females in the Swiss Alps and Jura Mountains, and $98-312 \mathrm{~km}^{2}$ in males, and $516 \mathrm{~km}^{2}$ in a female in Vosges Mountains (France). These figures are larger than data from Białowieża Forest (this study). The density of prey (roe deer: 7.7 inds $/ \mathrm{km}^{2}$ and chamois Rupicapra rupicapra: $5.0 \mathrm{inds} / \mathrm{km}^{2}$ ) in Swiss Alps (Breitenmoser and Haller 1987) is similar to that in BPF (4.9 roe deer and 5.4 red deer $/ \mathrm{km}^{2}$; Jędrzejewska et al. 1994). Thus, home ranges in reintroduced lynx population may be larger as a result of separation from the continuous range of the species and not yet stabilized social-spatial structure of the expanding population. Similarly, in a population of Canada lynx naturally colonizing Minnessota, Mech (1980) found considerably larger home ranges than those in stable populations. The size of home ranges in other natural populations of Eurasian lynx, although determined by snow-tracking, was 130 and $250 \mathrm{~km}^{2}$ for two males and $70 \mathrm{~km}^{2}$ for a female in western Russia (Zheltukhin 1984) and $300 \mathrm{~km}^{2}$ for an adult male in Sweden (Haglund 1966).

The body mass of Eurasian lynx from Białowieża Forest is twice that of the Canada lynx. One can then expect larger home ranges in the Eurasian lynx. In some regions, the mean home range of Canada lynx was small (eg $20-62 \mathrm{~km}^{2}$; Poole 1994), whereas in other places their ranges varied from 8 to $783 \mathrm{~km}^{2}$ (see Koehler and Aubry 1994 for review). Canada lynx rely on snowshoe hares Lepus americanus, which fluctuate greatly in numbers. During peak densities of hares, lynx population may reach density of 30 individuals per $100 \mathrm{~km}^{2}$ (Poole 1994), at which time the lynx occupy relatively small ranges (Ward and Krebs 1985, Poole 1994). Thus, prey density, also greatly influence the size of predator home ranges.

Comparison of home range size of Eurasian lynx and other solitary felids feeding on ungulates or other large mammals showed that the lynx maintain much bigger ranges than those of large-sized tropical cats: tigers Panthera tigris (60-72 km² ; Sunquist 1981), leopards Panthera pardus (27-96 km²; Rabinowitz 1989, Bailey 1993), and jaguars Panthera onca (97-168 $\mathrm{km}^{2}$; Crawshaw and Quigley 1991). On the other hand, Eurasian lynx's ranges were smaller than those of North American cougar (173 to $826 \mathrm{~km}^{2}$; Seidensticker et al. 1973, Hemker et al. 1984) inhabiting areas of highly mobile and seasonally changing prey populations living in low densities (Hornocker 1970). The deciduous and mixed forests of Białowieża (temperate zone of Europe) harbour a relatively rich community of 
ungulates (a crude biomass is about $1900 \mathrm{~kg} / \mathrm{km}^{2}$ : Jędrzejewska et al. 1994). They still, however, are much poorer in this respect than monsoonal forests of Asia $\left(18590 \mathrm{~kg} / \mathrm{km}^{2}\right.$; Seidensticker 1976) or African woodland-savanna $\left(6186 \mathrm{~kg} / \mathrm{km}^{2}\right.$; Bailey 1993).

\section{Spatial organization}

This study showed little home range overlap of female lynx. Females with kittens used as much area as needed to provide enough food for the kittens. We suggest that, if the food is sufficient, female home ranges are small. Thus, there is also little probability of the overlap. However, in a case of food shortage, they might be forced to share the same area. Such modifying of social organization was reported by Bailey (1974) in bobcats during rabbit scarcity.

Another factor in the female spatial organization may be kinship. Female cougars (Maehr et al. 1991, Laing and Lindzey 1993), leopards (Bailey 1993), and tigers (Smith et al. 1987) show a tendency to stay near or even inside their mothers' home ranges. In this study, the most extensive overlap between females was in the case of female Olga and two other females. Although Olga's range was not well known due to the state border, we cannot exclude that those females were closely related.

Larger overlap between life-time home ranges of male lynx may be caused by the increase of their home range sizes during the mating season. The case of Iwan and Trofim which showed $2-3 \%$ overlap of ranges in spring-summer 1995 and $20 \%$ in autumn-winter 1994/95 (Fig. 2) seems to corroborate this suggestion. It agrees with Sandell's (1989) opinion that overlapping ranges in males of solitary carnivores occur if there is a change in range size between the mating and non-mating season.

There are no consistent patterns in home range overlap in lynx and other large cat species (Seidensticker et al. 1973, Bailey 1974, 1993, Schaller and Crawshaw 1980, Sunquist 1981, Rabinowitz and Nottingham 1986, Crawshaw and Quigley 1991, Maehr et al. 1991, Breitenmoser et al. 1993, Poole 1995). As a rule, male home range encompassed those of one to several females, while there were varying extents of intrasexual overlap; the largest was usually recorded in females.

In Białowieża Forest, the home range of male lynx encompassed those of one or two females. This fact, together with lack of significant changes of home range size from autumn-winter to spring-summer seasons suggests that males maintain large ranges throughout the year to reduce competition for females during mating season. This is in accordance with the suggestion of Breitenmoser et al. (1993). On the other hand, males move outside their 'normal' range during the short mating season trying to meet as many females as possible. A good illustration of this relation was a female Diana, whose range overlapped totally with a male's range (Trofim), but also partly with that of the neighbouring male Iwan. 


\section{Territoriality and sociality in Eurasian lynx}

The Eurasian lynx appears to be territorial, according to the definition proposed by Davies (1978). Territoriality was especially evident in adult females. Although the ranges of adult males overlapped, they utilized the common area at different times. Extensive sharing of home range with an individual of the same sex was observed only in an adult and immature subadult pair. It is more difficult to interpret the relationships among males and females. Because males extensively overlapped ranges of females, it may suggest possibility of competitive interrelations between them. Nevertheless, a few recorded meetings between males and females indicates the tendency to use common area separately in time. The described example of alternative use of one prey by male and female lynx (Makary and Sonia) illustrates this tendency.

Lynx in BPF showed no clear tendency to socialize with conspecifics. Only females with their kittens spent much time together. Males were solitary and completely avoided other males. They socialized with females mainly during the mating season, and only occasionally at other times of year. Meetings outside the mating season may be caused by common use of a kill. However, the character of such meetings is unknown. The case of aggressive encounter between male Bazyliszek and female Natasza shows one of possible behaviours.

Mutual avoidance in the overlapping parts of home ranges is possible due to scent-marking (Macdonald 1985). In BPF, we observed urine and scat marking by lynx, while no scratching of trees. The scent-communication seems to be based on the use of the same paths and marking places by neighbouring individuals. Indeed, during this study, four adult males were captured in the same box trap, set during 3 years in one place (Makary and Nikifor in 1993 and Iwan and Trofim in 1995), and some snow-tracked individuals were using the same forest roads. This is contradictory to the suggestions on bobcat social organization (Bailey 1974) that a system of the paths in the home range allows cats to interpenetrate each other in the overlapping area and, consequently, to avoid violation of the owner's rights. In our opinion, overlapping ranges play an important role for exchange of information, especially because predators (lynx included), recognize the sex and age of conspecifics, and can differentiate familiar and unfamiliar individuals (Ewer 1973, Naidenko and Serbenyuk 1995). In conclusion, the spatial system in the lynx is based on territoriality, but it seems flexible enough to adjust the population to the changing conditions of the environment.

Acknowledgements: We are grateful to Urs and Christine Breitenmoser for their methodological instructions and help with obtaining equipment. R. Kowalczyk and S. Snieżko helped in radio-tracking of lynx. Mr A. Bunevich (State National Park Belovezhskaya Pushcha, Belarus) provided some radio-locations of lynx from the Belarussian part of BPF. We are indebted to Dr B. Jędrzejewska for valuable comments on an early draft of the paper and help in statistical analysis. Comments of Dr K. G. Poole and Dr T. Kvam are gratefully aknowledged. K. Zub prepared the figures. The study was financed by grant KBN 6P205 03405 . 


\section{References}

Anderson E. M. 1988. Effects of male removal on spatial distribution of bobcats. Journal of Mammalogy 69: 637-641.

Bailey T. N. 1974. Social organization in a bobcat population. Journal of Wildlife Management 38: $435-446$.

Bailey T. N. 1993. The African leopard. Ecology and behavior of a solitary felid. Columbia University Press, New York: 1-429.

Breitenmoser U. and Breitenmoser-Würsten C. 1990. Status, conservation needs and reintroduction of the lynx (Lynx lynx) in Europe. Nature and Environment Series, Strasbourgh: 1-47.

Breitemnoser U. and Haller H. 1987. Zur Nahrungsökologie des Luchses, Lynx lynx, in den Schweizerischen Nordalpen. Zeitschrift für Säugetierkunde 52: 168-191.

Breitenmoser U., Kaczensky P., Dötterer M., Breitenmoser-Würsten C., Capt S., Bernhart F. and Liberek M. 1993. Spatial organization and recruitment of lynx (Lynx lynx) in a re-introduced population in the Swiss Jura Mountains. Journal of Zoology, London 231: 449-464.

Carbyn L. N. and Patriquin D. 1983. Observation on home range sizes, movements and social organization of lynx, Lynx canadensis, in Riding Mountain National Park, Manitoba. The Canadian Field-Naturalist 97: 262-267.

Crawshaw P. G. and Quigley H. B. 1991. Jaguar spacing, activity and habitat use in a seasonally flooded environment in Brazil. Journal of Zoology, London 223: 357-370.

Davies N. B. 1978. Ecological questions about territorial behaviour. [In: Behavioural ecology. An evolutionary approach. J. R. Krebs and N. B. Davies, eds]. Blackwell Scientific Publications, Oxford: $317-350$.

Dunker H. 1988. Winter studies on the Lynx Lynx lynx L. in Southeastern Norway from 1960-1982. Meddelelser fra Norsk Viltforskning 19: 1-56.

Ewer R. F. 1973. The carnivores. Cornell University Press, Ithaca, New York: 1-494.

Faliński J. B. 1986. Vegetation dynamics in temperate lowland primeval forest. Dr. W. Junk Publishers, Dordrecht, Geobotany 8: 1-537.

Giddings B. 1986. Ecology of the bobcat in a prairie rangeland-agricultural environment in eastern Montana. (Home range size, movements and habitat use of bobcats in a prairie rangeland environment). Unpublished progress report, Montana Department of Fish, Wildlife and Parks: $1-62$.

Goszczyński J. 1986. Locomotor activity of terrestrial predators and its consequences. Acta Theriologica 31: 79-95

Haglund B. 1966. Winter habits of the lynx (Lynx lynx L.) and Wolverine (Gulo gulo L.) as revealed by tracking in the snow. Viltrevy 4: 81-310. [In Swedish with English summary]

Haller H. and Breitenmoser U. 1986. Zur Raumorganisation der in den Schweizer Alpen wiederangesiedelten Population des Luchses ( $\operatorname{ly} x x \operatorname{lyn} x$ ). Zeitschrift für Säugetierkunde 51: 289-311.

Harris S., Cresswell W. J., Forde P. G., Trewhella W. J., Woolard T. and Wray S. 1990. Home-range analysis using radio-tracking data - a review of problems and techniques particularly as applied to the study of mammals. Mammal Review 20: 97-123.

Hayne D. W. 1949. Calculation of size of home range. Journal of Mammalogy 30: 1-18.

Hemker T. P., Lindzey F. G. and Ackerman B. B. 1984. Population characteristics and movement patterns of cougars in southern Utah. Journal of Wildlife Management 48: 1275-1284.

Herrendschmidt V., Léger F. and Terrier G. 1986. Mode d'occupation spatiale des lynx (Felis lynx L.) introduits dans les Massif Vosgien, premiers résultats. Gibier Faune Sauvage 3: 67-81.

Hornocker M. G. 1970. An analysis of mountain lion predation upon mule deer and elk in the Idaho Primitive Area. Wildlife Monographs 21: 1-39.

Jędrzejewska B., Okarma H., Jędrzejewski W. and Miłkowski L. 1994. Effects of exploitation and protection on forest structure, ungulate density and wolf predation in Białowieża Primeval Forest, Poland. Journal of Applied Ecology 31: 664-676. 
Jędrzejewski W., Schmidt K., Miłkowski L., Jędrzejewska B. and Okarma H. 1993. Foraging by lynx and its role in ungulate mortality: the local (Białowieża Forest) and the Palearctic viewpoints. Acta Theriololgica 38: 385-403.

Jędrzejewski W., Jędrzejewska B., Okarma H., Schmidt K., Bunevich A. and Miłkowski L. 1996. Population dynamics (1869-1994), demography and home ranges of the lynx in Białowieża Primeval Forest (Poland and Belarus). Ecography 19: 122-138.

Koehler G. M. and Hornocker M. G. 1989. Influences of seasons on bobcats in Idaho. Journal of Wildlife Management 53: 197-202.

Koehler G. M. and Aubry K. B. 1994. Lynx. IIn: Scientific basis for conserving forest carnivores: American marten, fisher, lynx and wolverine in the western United States. L. F. Ruggiero, K. B. Aubry, S. W. Buskirk, L. J. Lyon and W. J. Zielinski, eds]. General Technical Report RM-254. Ft. Collins. USDA Forest Service: 74-98.

Kvam T. 1991. Reproduction in the European lynx, Lynx lynx. Zeitschrift für Säugetierkunde 56: 146-158.

Laing S. P. and Lindzey F. G. 1993. Patterns of replacement of resident cougars in southern Utah. Journal of Mammalogy 74: 1056-1058.

Litvaitis J. A., Sherburne J. A. and Bissonette J. A. 1986. Bobcat habitat use and home range size in relation to prey density. Journal of Wildlife Management 50: 110-117.

Litvaitis J. A., Major J. T. and Sherburne J. A. 1987. Influence of season and human-induced mortality on spatial organization of bobcats (Felis rufus) in Maine. Journal of Mammalogy 68: 100-106.

Lovallo M. J. and Anderson E. M. 1995. Range shift by a female bobcat (Lynx rufus) after removal of neighboring female. American Midland Naturalist 134: 409-412.

Macdonald D. W. 1985. The carnivores: order Carnivora. In: Social odours in mammals. R. E. Brown and D. W. Macdonald, eds]. Clarendon Press, Oxford: 619-722.

Maehr D. S., Land E. D. and Roof J. C. 1991. Social ecology of Florida panthers. National Geographic Research and Exploration 7: 414-431.

Matjuschkin E. N. 1978. Der Luchs. Die Neue Brehm-Bücherei, Wittenberg Lutherstadt 517: 1-160.

Mech L. D. 1980. Age, sex, reproduction, and spatial organization of lynxes colonizing northeastern Minnesota. Journal of Mammalogy 61: 261-267.

Mech L. D. 1983. Handbook of animal radio-tracking. University of Minnesota Press, Minneapolis: 1-107.

Naidenko S. V. and Serbenyuk M. A. 1995. Urine marking in European lynx. 2nd European Congress of Mammalogy. Abstract book. Southampton University: 126.

Okarma H., Jędrzejewska B., Jędrzejewski W., Krasiński Z. and Miłkowski L. 1995. The roles of predation, snow cover, acorn crop, and man-related factors on ungulate mortality in Bialowieża Primeval Forest, Poland. Acta Theriologica 40: 197-217.

Okarma H., Jędrzejewski W., Schmidt K., Kowalczyk R., and Jędrzejewska B. 1997. Predation of Eurasian lynx on roe deer and red deer in the Białowieża Primeval Forest, Poland. Acta Theriologica 42: 203-224.

Olszewski L. 1986. The role of forest ecosystems in modifying local climate of Białowieża Primeval Forest, as revealed by air temperature characteristics. Prace habilitacyjne, Ossolineum, Wrocław: 1-222. [In Polish with English summary]

Parker G. A. 1978. Searching for mates. IIn: Behavioural ecology. An evolutionary approach. J. R. Krebs and N. B. Davies, eds]. Blackwell Scientific Publications, Oxford, London: 214-244.

Parker G. R., Maxwell J. W. and Morton L. D. 1983. The ecology of the lynx (Lynx canadensis) on Cape Breton Island. Canadian Journal of Zoology 61: 770-786.

Poole K. G. 1994. Characteristics of an unharvested lynx population during a snowshoe hare decline. Journal of Wildlife Management 58: 608-618.

Poole K. G. 1995. Spatial organization of a lynx population. Canadian Journal of Zoology 73: 632-641. 
Pulliainen E. 1980. Winter diet of Felis lynx L. in SE Finland as compared with the nutrition of other northern lynxes. Zeitschrift für Säugetierkunde 46: 249-259.

Quinn N. W. S. and Parker G. 1987. Lynx. IIn: Wild furbearer management and conservation in North America. M. Novak, J. A. Baker, M. E. Obbard and B. Malloch, eds]. Ministry of Natural Resources, Ontario: 191-215,

Rabinowitz A. 1989. The density and behavior of large cats in a dry tropical forest mosaic in Huai Kha Khaeng Wildlife Sanctuary, Thailand. Natural History Bulletin of Siam Society 37: 235-251.

Rabinowitz A. R and Nottingham B. G. 1986. Ecology and behaviour of the Jaguar (Panthera onca) in Belize, Central America. Journal of Zoology, London 210: 149-159.

Sandell M. 1989. The mating tactics and spacing patterns of solitary carnivores. [In: Carnivore behavior, ecology, and evolution. J. L. Gittleman, ed]. Chapman and Hall, London: 164-182.

Schaller G. B. and Crawshaw P. G. 1980. Movement patterns of jaguar. Biotropica 12: 161-168.

Seal U. S. and Kreeger T. J. 1987. Chemical immobilization of furbearers. [In: Wild furbearer management and conservation in North America. M. Novak, J. A. Baker, M. E. Obbard and B. Malloch, eds]. Ministry of Natural Resources, Ontario: 191-215.

Seidensticker J. C., Hornocker M. G., Wiles W. V. and Messick J. P. 1973. Mountain lion social organization in the Idaho Primitive Area. Wildlife Monographs 35: 1-60.

Seidensticker J. 1976. Ungulate populations in Chitawan Valley, Nepal. Biological Conservation 10: $183-210$.

Smith J. L. D., McDougal C. W. and Sunquist M. E. 1987. Female land tenure system in tigers. IIn: Tigers of the world. R. L. Tilson and U. S. Seal, eds]. Noyes Publications, New Jersey: 97-109.

Sunquist M. E. 1981. The social organization of tigers (Panthera tigris) in Royal Chitawan National Park, Nepal. Smithsonian Contributions to Zoology 336: 1-98.

Shubin N. G. 1967. Some facts about the ecology of the lynx in West Siberia. [In: Problemy Ekologii]. Tomsk: 240-246. [In Russian with English summary]

Ward R. M. P. and Krebs C. J. 1985. Behavioural responses of lynx to declining snowshoe hare abundance. Canadian Journal of Zoology 63: 2817-2824.

Worton B. J. 1989. Kernel methods for estimating the utilization distribution in home-range studies. Ecology 70: 164-168.

Yurgenson P. B. 1955. [On ecology of the lynx in the forests of the middle zone of USSR]. Zoologicheskii Zhurnal 34: 609-620. [In Russian]

Zheltukhin A. S. 1984. Daily activity and sizes of home ranges of the European lynx in the southern taiga of the Upper Volga River Region. Byulleten Moskovskogo Obshchestva Ispytatelei Prirody, Otdelenie Biologii 89: 54-62. [In Russian with English summary]

Zheltukhin A. S. 1986. Biocenotic relationships of the European lynx (Lynx lynx) in the southern taiga of the Upper Volga. Zoologicheskii Zhurnal 65: 259-271. [In Russian with English summary] 
Appendix. Eurasian lynx radio-tracked in Białowieża Primeval Forest from February 1991 to Narch 1996. ${ }^{\mathrm{a}}$ The lynx located also in the Belarussian part of BPF. ${ }^{\mathrm{b}}$ Body masses of the lynx at consecutive recaptures. ? - no data.

\begin{tabular}{|c|c|c|c|c|c|c|c|}
\hline No. & $\begin{array}{l}\text { Lynx's } \\
\text { name }\end{array}$ & Sex & $\begin{array}{l}\text { Age at } \\
\text { capture }\end{array}$ & $\begin{array}{l}\text { Body mass } \\
(\mathrm{kg})\end{array}$ & Time of monitoring & $\begin{array}{l}\text { Total number } \\
\text { of locations }\end{array}$ & Fate \\
\hline 1 & Bazyli $^{\mathrm{a}}$ & M & Adult & 20 & 24 Feb-23 Dec'91 & 101 & Poached \\
\hline \multirow[t]{2}{*}{2} & Makary $^{\mathrm{a}}$ & M & Adult & $19,23^{b}, 20^{b}$ & 9 Mar-3 Jun'91 & 54 & Collar failure \\
\hline & & & & & 27 Feb'93-20 Apr'94 & 143 & Collar failure \\
\hline 3 & Mały & M & 7 months & 9 & 11 Dec'91-21 Jan'92 & 18 & Dispersed \\
\hline 4 & Borys & M & Adult & 24 & 7 Feb-7 Dec'92 & 59 & Poached \\
\hline 5 & Bazyliszek & M & 9 months & $11,14^{\mathrm{b}}$ & 10 Feb'92-4 Jan'94 & 177 & Poached \\
\hline 6 & $\mathrm{Zoja}^{\mathrm{a}}$ & $\mathrm{F}$ & 8 months & 10 & 5 Jan'93-24 Aug'94 & 59 & Collar failıre \\
\hline 7 & Nikifor & M & Adult & 21 & 25 Jan-23 Feb'93 & 15 & Rabid \\
\hline 8 & Sonia $^{a}$ & $\mathrm{~F}$ & Subadult & 15 & 30 Jan'93-8 Apr'95 & 461 & Collar failure \\
\hline 9 & Natasza & $\mathrm{F}$ & Adult & 16.5 & 3 Feb'93-28 Mar'94 & 173 & Emigratec \\
\hline 10 & $\mathrm{Olga}^{a}$ & $\mathrm{~F}$ & Adult & 15 & 16 Feb-6 Sep'94 & 19 & Collar failıre \\
\hline 11 & Igor & M & Subadult & 16 & 22 Mar-27 Nov'94 & 145 & Shot \\
\hline 12 & Tamara & $\mathrm{F}$ & Subadult & 15 & 29 Mar-22 Aug'94 & 117 & Died \\
\hline 13 & Nikita $^{a}$ & M & 6 months & 8 & 16 Nov'94-14 Aug'95 & 126 & Dispersed \\
\hline 14 & Lena & $\mathrm{F}$ & 8 months & 10.5 & 20 Jan-29 Apr'95 & 55 & Dispersed \\
\hline 15 & Dymitr $^{a}$ & M & 8 months & 9 & 24 Jan-9 Sep'95 & 75 & Dispersed \\
\hline 16 & $\operatorname{Iwan}^{\mathrm{a}}$ & M & Adult & 25 & 13 Feb'95-7 Mar'96 & 215 & Collar failure \\
\hline 17 & Diana & $\mathrm{F}$ & Adult & 19.5 & 4 Mar-3 Aug'95 & 112 & Collar failure \\
\hline 18 & Trofim & M & Adult & $?$ & 18 Mar'95-20 Mar'96 & 241 & $\begin{array}{l}\text { Still tracked } \\
\text { after Mar } 1996\end{array}$ \\
\hline
\end{tabular}

